\title{
Facilitating public participation in water resources management: reflections from Tanzania
}

\author{
$\underline{\text { Jane Eleuter Kabogo }}^{1}$, Elizabeth P. Anderson $^{2}$, Pendo Hyera $^{3}$ and $^{\text {Godfred Kajanja }}{ }^{4}$
}

\begin{abstract}
Access to adequate quantity and quality of fresh water is critical to the well-being of Tanzania's human population, currently approaching 50 million. In the early 2000s, Tanzania revamped its legal and institutional frameworks related to freshwater resources management with the passage of the National Water Policy (NAWAPO) and the Water Resources Management (WRM) Act. Three major components of these frameworks are: the use of natural hydrological boundaries as units for management; the designation of an order for decision making on water allocation that prioritizes basic human and ecosystem water needs; and the encouragement of community participation in freshwater resources management. Institutionally, WRM now follows a nested approach, with the Tanzanian Ministry of Water operating at a national scale, nine basin water offices responsible for water allocation at a river basin scale, and formally recognized water users' associations as mechanisms for public participation at the catchment scale. To date, 93 water users' associations have been formed. Although some are active and appear effective, others are almost dormant, and not achieving their full potential as partners in WRM. In this paper, we provide context for the sweeping changes in WRM in Tanzania and review the lessons from more than a decade of implementation of the NAWAPO. We focus in particular on the role of the water users' associations, and use case studies of three basins - the Pangani, Wami/Ruvu, and Lake Victoria-to examine their strengths and challenges. Tanzania's experience offers lessons for other countries considering revision to legal and institutional frameworks around fresh water.
\end{abstract}

Key Words: East Africa; freshwater; people; river; water users' associations

\section{INTRODUCTION}

The policy and practice of freshwater resources management have evolved to embrace the principles of integrated water resource management (IWRM) over the past half-century (Subramanian et al. 1997, Brown 2011, van Koppen et al 2016). These changes have been largely in response to the issuance of principles at the 1992 Dublin Conference on Water and Environment that: recognized water as a finite resource; advocated a participatory approach to water management; heralded the importance of women in provision, management, and safeguarding of water; and established the economic and social value of water resources. The IWRM narrative also promotes three concurrent goals of equitable access to water resources, environmental sustainability, and economic efficiency of water use (van Koppen et al. 2016). National or regional applications of IWRM - for example, in South Africa, Tanzania, and under the European Water Framework Directive - have enshrined participatory management in water resources at a basin scale, following natural hydrological boundaries (Jacobs et al. 2010, Brown 2011). A participatory approach to water management is viewed as having greater likelihood of empowering local people, including traditionally disadvantaged groups, and greater effectiveness in sustainable water resource provision (Cleaver and Toner 2006).

The ways that stakeholders participate in water resource management (WRM) vary and can have wide-ranging environmental, social, political, and economic consequences (Butler and Adamowski 2015). Cohen and Uphoff (1977) discuss the importance of identifying what kind of participation is desired, whose participation is of interest, and how participation occurs. Institutional and organizational arrangements for facilitating public participation are highly diverse and continually evolving, and their performance has not been thoroughly examined (Ostrom 1990, Jacobs et al. 2010). In some cases, traditional resource management - referring to the application of local ecological knowledge through customs and social norms for utilization, distribution, and regulation of natural resources- has facilitated stakeholder participation (Vollan and Ostrom 2010, Strauch and Almedom 2011). Stakeholder participation can also occur through groupings of similar users, such as irrigation boards in South Africa (Brown 2011). Water users' associations (WUA) exist as another mechanism to facilitate stakeholder participation in WRM. These WUAs are often formally recognized and nested within a clearly established hierarchy for water management; they represent a managed decentralization of WRM, operating at a catchment scale with inhabitants of that catchment but linked to a larger basin or national-scale institution (Subramanian et al. 1997).

Although WUAs are recognized as appropriate institutions for stakeholder participation, their implementation in practice has fallen short of expectations. Experiences related in Becker and Ostrom (1995) suggest that for WUAs to be robust institutions, at a minimum they should be part of nested institutional hierarchy and have clearly defined boundaries - both jurisdictionally and geographically. Studies of WUAs in South Africa indicate that dynamic and effective leadership is vital; when this leadership is lacking or withdrawn, WUAs flounder (Brown 2011). Sufficient and clear incentives for participation are critical to the success and sustainability of WUAs, perhaps more than any other single factor (Subramanian et al. 1997). Additionally, Ostrom (1990) suggested a set of conditions that commonly could influence outcomes of governance structures like WUAs, among those the number of decision makers, their similarities of interests, and the presence of participants with assets or other leadership.

\footnotetext{
${ }^{1}$ Ministry of Water and Irrigation, United Republic of Tanzania, Dar es Salaam, Tanzania, ${ }^{2}$ Department of Earth and Environment, Florida International University, Miami, Florida, USA, ${ }^{3}$ Wami/Ruvu Basin Water Board, Ministry of Water and Irrigation, United Republic of Tanzania, Morogoro, Tanzania, ${ }^{4}$ Lake Victoria Basin Water Board, Ministry of Water and Irrigation, United Republic of Tanzania, Mwanza, Tanzania
} 
Table 1. Sustainability considerations for participatory water users' associations (WUAs), based on factors identified by existing studies to affect functioning of WUAs.

\begin{tabular}{|c|c|c|}
\hline Theme & Questions & Relevant studies \\
\hline \multicolumn{3}{|c|}{ Structural Considerations } \\
\hline Management & $\begin{array}{l}\text { - Do WUAs have clearly defined roles and responsibilities? } \\
\text { - Is the jurisdictional geographic area of WUAs well defined? } \\
\text { - Do WUAs have mechanisms and capacity for conflict management? }\end{array}$ & Becker and Ostrom 1995, Mehari et al. 2009 \\
\hline Flexibility & $\begin{array}{l}\text { - Are there mechanisms for feedback on WUA activities and management? } \\
\text { - Is adaptive management encouraged? } \\
\text { - Are there possibilities to draw on traditional resource management } \\
\text { approaches when applicable? }\end{array}$ & $\begin{array}{l}\text { Subramanian et al. 1997, Sokile et al. 2003, } \\
\text { Strauch and Almedom } 2011\end{array}$ \\
\hline \multicolumn{3}{|c|}{ Operational Considerations } \\
\hline Leadership & $\begin{array}{l}\text { - Do WUAs have dynamic and effective leadership? } \\
\text { - Do WUA leaders treat all members equally and refrain from favoritism? } \\
\text { - Are WUA leaders able to enforce rules and regulations? }\end{array}$ & Brown 2011, Lalika et al. 2015 \\
\hline $\begin{array}{l}\text { Community } \\
\text { participation }\end{array}$ & $\begin{array}{l}\text { - Is there broad awareness and understanding of the WUA's purpose? } \\
\text { - Are there sufficient incentives for participation? } \\
\text { - Do WUAs meet regularly? } \\
\text { - Does the WUA comprise a heterogeneous group? }\end{array}$ & $\begin{array}{l}\text { Subramanian et al. 1997, Cleaver and Toner } \\
\text { 2006, Lalika et al. 2015, van Koppen et al. } 2016\end{array}$ \\
\hline Finance & $\begin{array}{l}\text { - Does the WUA have sufficient funds to operate? } \\
\text { - Are there opportunities or mechanisms for external support? } \\
\text { - Does the WUA practice sound accounting and financial transparency? }\end{array}$ & Subramanian et al. 1997, Lalika et al. 2015 \\
\hline \multicolumn{3}{|c|}{ Performance Considerations } \\
\hline IWRM & $\begin{array}{l}\text { - Do WUAs improve equitable water use? } \\
\text { - Do WUAs improve economic efficiency of water use? } \\
\text { - Do WUAs improve environmental sustainability? } \\
\text {-Do WUAs provide credible assistance to Basin Water Offices? }\end{array}$ & $\begin{array}{l}\text { Mehari et al. 2009, Komakech and van der Zaag } \\
\text { 2011, Lalika et al. 2015, van Koppen et al. } 2016\end{array}$ \\
\hline
\end{tabular}

Experiences in the East African country of Tanzania illustrate the growing appreciation for stakeholder participation in WRM and the challenges of its implementation. Over the past three decades, Tanzania revamped its legal and institutional frameworks for governance of freshwater resources. The National Water Policy (NAWAPO) of 2002 and subsequent Water Resources Management Act No. 11 (WRM Act) of 2009 maintained natural hydrological boundaries (basins) as units for management, designated an order for decision making on water allocation that prioritizes basic human and ecosystem water needs, and formalized community participation in freshwater resources management (United Republic of Tanzania (URT) 2002, 2009). Institutionally, freshwater resources management follows a nested approach, with the Tanzanian Ministry of Water and Irrigation operating at a national scale, nine basin water boards responsible for water allocation at a basin scale, catchment water committees operating at a catchment scale, and formally recognized WUAs as mechanisms for public participation at subbasin levels. As a result, Tanzania presently has among the strongest enabling legal environments for sustainable freshwater resources management worldwide. Additionally, more than a decade of implementation of the NAWAPO has provided valuable lessons, especially in terms of WUAs as mechanisms for stakeholder participation.

In this paper, we reflect on the progress to date in facilitating stakeholder participation in WRM in Tanzania. We provide an overview of Tanzania's current legal and institutional frameworks for freshwater resources management, with a focus on stakeholder participation and WUAs. We review the progress made nationally on formation of legally recognized WUAs. We then examine the challenges and sustainability of WUAs, focusing on three basins: the Pangani, Lake Victoria, and Wami/Ruvu. Finally, we propose a set of recommendations for making public participation in freshwater resources management in Tanzania effective and sustainable. Our intent is to document status and trends with WUAs in Tanzania thus far, and to share experiences and lessons that may be informative for other developing nationsparticularly in sub-Saharan Africa-seeking to institutionalize public participation in freshwater resources management.

Information presented in this paper was drawn from multiple sources. Review of official documents and primary literature provided baseline and contextual information on IWRM in Tanzania. This information was complemented by first-hand knowledge in the development of new frameworks for water management in Tanzania through more than a decade of direct experience of all coauthors either working for or collaborating with the Tanzanian Ministry of Water and Irrigation. For the three case studies, we collected information from the primary literature as well as our own experiences in the field conducting interviews with WUA members and participant observation at WUA meetings. Three of the coauthors on this paper have been directly involved in establishing and supporting WUAs in the Pangani, Wami/Ruvu, and Lake Victoria Basins (Kabogo, Hyera, and Kajanja, respectively), and one also has provided guidance on WUAs at a national scale (Kabogo). To make case-study assessments more objective and systematic, we created a list of six sustainability considerations for WUAs based on experiences published in the primary literature (Table 1). Our review of WUA 
Fig. 1. Map of Tanzania, showing the nine major basins. Source: Tanzanian Ministry of Water.

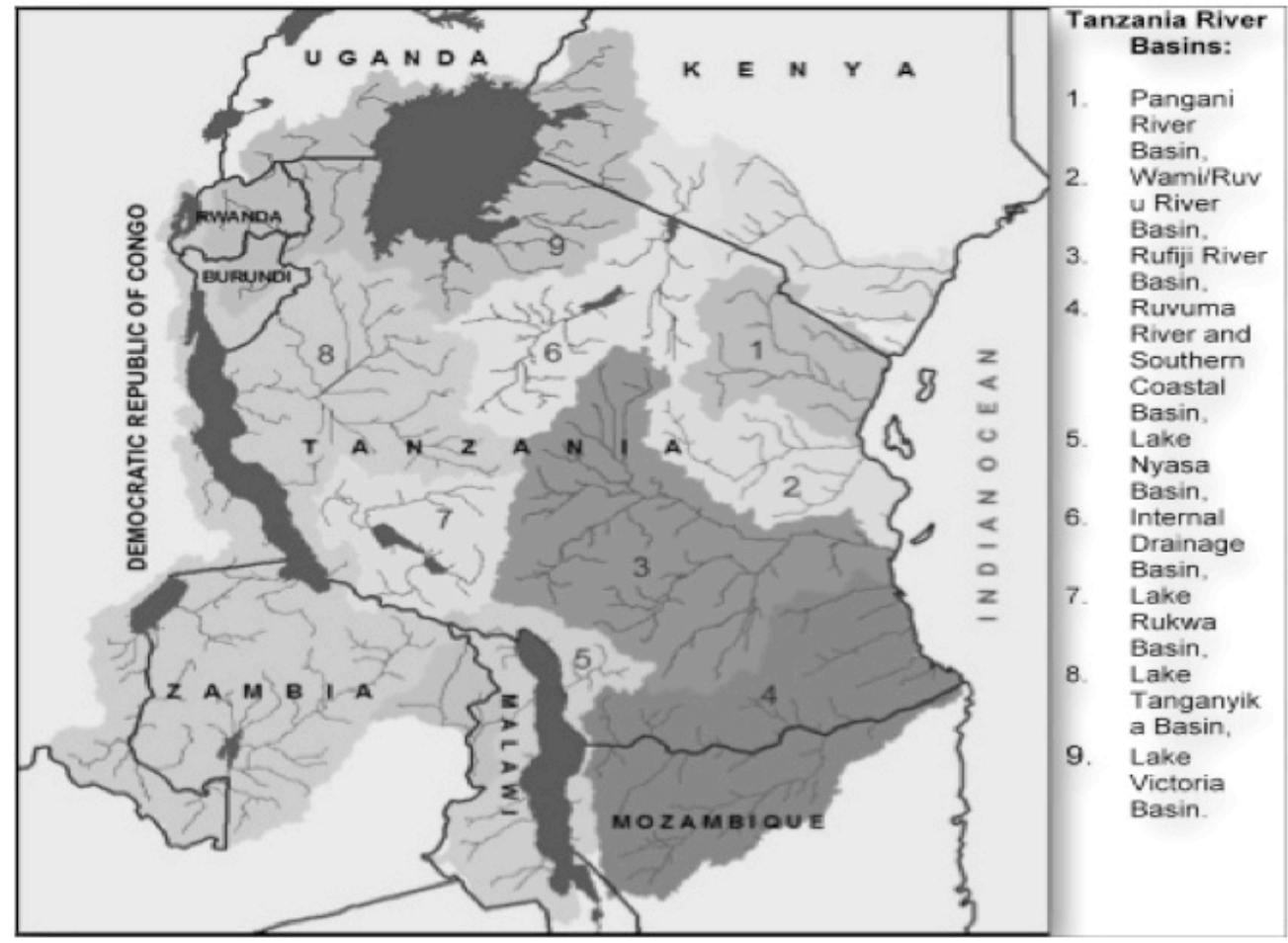

experiences in each basin attempts to reflect on as many of these considerations as possible, given published studies or hands-on knowledge.

\section{THE TANZANIAN CONTEXT FOR FRESHWATER MANAGEMENT}

The current status and trends of freshwater management in Tanzania-including those related to WUAs and stakeholder participation - were influenced by numerous political and social shifts over the past century. Precolonial water governance in Tanzania typically followed customary laws and aligned with the needs and realities of indigenous water users (Komakech et al. 2011); in many cases, mwene (local chiefs) oversaw rotation-based water-sharing systems at the sub or village level (Mehari et al. 2009). During the colonial period, formal water law was introduced by German and British settlers in the early 1900s, declaring all surface and ground waters to be property of the colonial government (Maganga 2003). Following independence in 1961, Tanzania's early water-related policies focused on technical issues and included limited consideration of community participation in freshwater resources management or of natural hydrological boundaries. At this time, freshwater resources were managed by regional water engineers, but the lines of their jurisdiction followed political or administrative boundaries, rather than basin or natural limits. Conflicts arose that were linked to this mismatch, as many of the country's large rivers passed through various administrative regions, but there were few if any effective platforms for discussion and resolution of conflicts (Mehari et al. 2009).

Tanzania shifted its approach in the 1980s, making hydrological basins the focus of water management (Cleaver and Toner 2006, van Koppen et al. 2016). The country created a system of basin water offices and basin water boards, starting with the Pangani Basin in 1991, and followed soon after by the Rufiji Basin; these two basins were considered critical because their rivers generate an important part of Tanzania's electricity. In essence, the mandate of the basin water offices as first established was to rein in and gain control of water resources use and development by: registering and regulating all forms of water use in the basin, issuing formal water rights to users, and introducing and collecting water user fees (Komakech et al. 2011). Seven more basin offices have been established since the 1990s (Fig. 1).

Tanzania is now one of many countries that endorses the concept of integrated water resources management and development (IWRMD) and adheres to the Dublin Principles (van Koppen et al. 2016). These principles - and especially a focus on stakeholder or public participation in freshwater resources management - are manifested in the three main pieces of Tanzanian freshwater governance: the NAWAPO of 2002, the National Water Sector Development Strategy (NWSDS) of 2006, and the WRM Act of 2009.

The current institutional framework for freshwater resources management was conceived in order to facilitate harmonious integration and participation of all stakeholders, advocating polycentric governance (Cleaver and Toner 2006). The NAWAPO identifies five water-management levels, namely the national, basin, district, catchment/subcatchment, and WUA (Fig. 2). The national-level body responsible for coordination, policy, and regulation is the Tanzanian Ministry of Water and Irrigation, which is advised on all issues related to fresh water by the National Water Board. This National Water Board comprises members 
Fig. 2. Schematic of the institutional framework for freshwater resources management in Tanzania. Source: Tanzania Water Sector Development Programme 2006-2025, Tanzanian Ministry of Water.

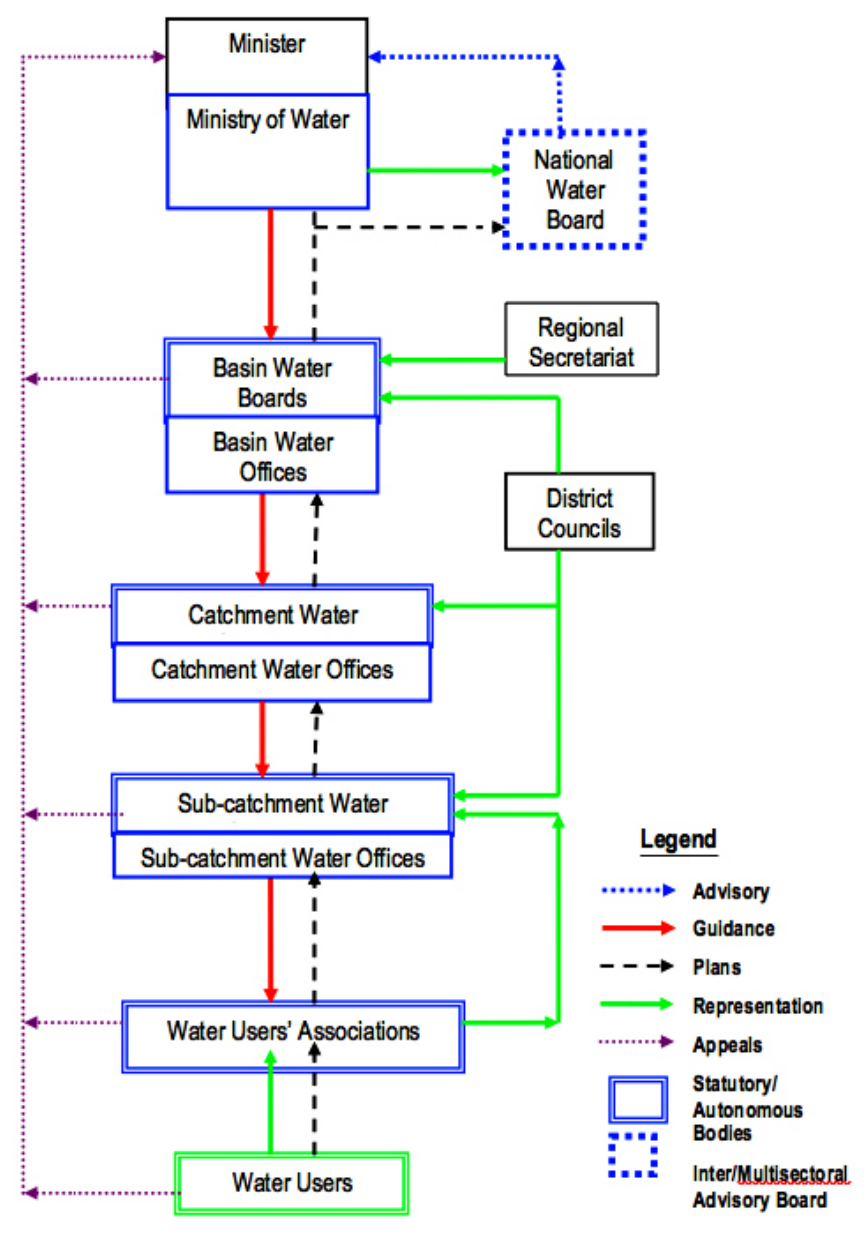

from different ministries and different sectors (e.g., agriculture, mining, tourism). Each of the nine identified basins in Tanzania (Fig. 1) is managed by a basin water board (BWB), composed of 10 members who are representatives of local governments, catchment committees, WUAs, and different sectors. Basin water boards meet quarterly and play an executive function at the basin level by approving water permits, budgets, and management plans. A basin water officer serves as the secretary to this board and is supported by a staff in a basin water office (BWO). Catchment water committees (CWC), designed to be an intermediate level of management, are intended to have five members and be formed by representatives of WUAs. Their main functions, as per the WRM Act of 2009, are to coordinate IWRM plans, resolve water resources conflicts in the catchment, and perform other functions as delegated by the BWB (URT 2009). To date, few catchment committees have actually been formed. Finally, WUAs assist the BWB by overseeing water source protection and navigating local conflicts over water. The WUAs are the primary vehicle for formal stakeholder and public participation in freshwater resources management.
In Tanzania, a WUA is intended to be the smallest WRM entity, and each WUA is registered independently. However, multiple WUAs all within the same basin could unite to form an apex WUA or catchment committee (see Mehari et al. 2009). The objectives of a WUA include conservation of water catchments, promotion of sustainable WRM, increased availability of water resources, increased use of fresh water for economic and social improvements, and development of sustainable and responsive institutions. In theory, WUAs could collaborate on the determination and implementation of environmental flowsreferring to the quantity, quality, and timing of fresh water needed for ecosystems and ecosystem services - as per the NAWAPO of 2002 and WRM Act of 2009. But in practice, there has been limited experience of WUAs in Tanzania contributing to environmental flow assessment studies in the Pangani, Wami/ Ruvu, Lake Victoria, or Rufiji Basins.

The formation of WUAs is a legal requirement, according to the WRM Act of 2009, and every water user group in a basin-for instance, small farmers, domestic users, industrial users, and commercial agriculture-must have representation within a WUA. The process of WUA formation follows several steps, broken down into four main phases. First, the Identification Phase includes delineation and collection of baseline data on the catchment, and stakeholder identification and analysis. Second, the Mobilization Phase allows for awareness building campaigns about the WUA among stakeholders. Third, the Organizing Phase entails participatory assessments of water resources and planning for future data collection. This phase marks the official formation of the WUA, as it also includes preparation of a constitution and registration of the WUA. The fourth and final phase, Capacity Building, ideally extends into the life of the WUA and involves institutional and individual training to prepare the WUA to undertake essential tasks as an autonomous management organization. Once operational, each WUA itself also has a detailed governance structure under Tanzanian policy.

A few additional intricacies about WUAs in Tanzania merit mention, as described in the WRM Act of 2009 (URT 2009; Table 2). First, women are given special consideration in leadership of WUAs, with one-third of all committees or different levels of leadership to comprise women. Second, there is no fixed size for the geographic area encompassed by a WUA nor for the number of members. Hydrological boundaries are used to define area and membership. Experiences from the Pangani Basin — which was an early implementer of water policies and formation of WUAsillustrate the variation in size of WUAs both in terms of geographic area and number of members. In the Pangani, a large WUA covers $>2,000 \mathrm{~km}^{2}$ and has ca. 80 members; smaller WUAs may cover $<1,000 \mathrm{~km}^{2}$ and have only 10-20 members (J. Kabogo, unpublished data). Third, rules for WUAs observe existing Tanzanian water laws, but some determinations may be made internally by the WUA. Jurisdictions between WUAs and local governments are clear in Tanzanian laws, but confusion may arise when people are not adequately familiar with those laws. And finally, WUAs play a role in issuance of water permits and collection of water fees, in close consultation with the relevant BWB. Specifically, where a WUA exists, the WUA is supposed to assist with collection of water fees and should be able to revise and give opinions on water permit requests, as per the WRM Act of 2009. But to date, because of low capacity to carry out functions, few WUAs have agreements with BWBs to administer 
Table 2. Roles and responsibilities of water users' associations (WUAs) in Tanzania (Source: Tanzania Water Resources Management Act No. 11, 2009).

Primary roles of the WUA:

(i) to manage, distribute, and conserve water from a source used jointly by the members of the association

(ii) to acquire and operate any permit under the provision of this Act

(iii) to resolve conflicts between members of the association related to the joint use of water or a water resource

(iv) to collect water user fees on behalf of the Basin Water Board

(v) to represent the special interests and values arising from water used for a public purpose, such as in an environmental and conservation area, or a groundwater controlled area. This also includes representation of stakeholder' needs at higher levels of water management.

Other functions of a WUA may include:

(i) exchange information and ideas on water resource use

(ii) monitor water availability

(iii) provide technical assistance in areas such as soil, water, and crop management, livelihood diversification, marketing, finance, and savings

(iv) discuss potential projects and development (including climate change) that may affect water usage

(v) operate and maintain a water service or structure

(vi) management of a water distribution system, including setting tariffs and collecting fees.

A WUA may be formed by the agreement of the majority of a group of water users for one or a combination of the following purposes, to:

(a) manage, distribute, and conserve water from a source used jointly by the members of the WUA;

(b) acquire and operate any permit under the provisions of this Act;

(c) resolve conflicts between members of the association related to the joint use of a water resource;

(d) collect water user fees on behalf of the Basin Water Board; and

(e) represent the special interests and values arising from water used for a public purpose, such as in an environmental or conservation area, or for the purpose of managing a Groundwater Controlled Area.

The Association of water users for the purpose of subsection (1) shall comprise of any user of water from a common stream irrespective of the purpose of that use.

fee collection and have provided limited input on water permit request reviews.

\section{WATER USERS' ASSOCIATIONS: PROGRESS AND CHALLENGES}

To date, 102 WUAs have been formed in Tanzania under the NAWAPO and WRM Act. Leadership in setting up WUAs has frequently been provided by community development officers and other staff from BWOs, and by external consultants supported by donor funds (Cleaver and Toner 2006). The order of priority for establishing WUAs has been subjected to many factors. Local interests for formation of a WUA have included increased connection with decision makers at a basin scale and water conflict resolution (Lalika et al. 2015). The Tanzanian Ministry of Water and Irrigation and BWBs' interest in registering water users and collection of water fees has provided impetus in certain areas; water fees are part of a global trend based on the premise that they help promote more efficient use of water and could help BWBs finance themselves (Komakech et al. 2011). Membership in WUAs has been obtained through one-time payment of membership and annual fees and participation in communal labor (Cleaver and Toner 2006), although the fee and the labor (or other requirement) vary by WUA.

Water users' associations provide a support system, at a catchment scale, to the BWB and are part of a formal, nested hierarchy in water management. The WUAs also have a seat on the respective BWB, which provides a voice for local-level stakeholders in basinscale decisions. Formalized committees, constitutions, and bank accounts that exist for each WUA can provide structure and order to the WUA itself. Studies from Tanzania suggest that WUAs could be helpful in providing accountability at higher management levels with respect to water supply and infrastructure development, or with capacity building at the WUA level (Mehari et al. 2009). Insights from Tanzania suggest that formal mechanisms for stakeholder participation, linked to the government, may be beneficial in basins with water infrastructure (Strauch and Almedom 2011). Some WUAs have spearheaded community-based or income-generation activities in their areas of jurisdiction. These activities are often unrelated to WRM; common examples are beekeeping (which has long been promoted by development organizations in Tanzania), tree nurseries, or small-scale agricultural activities. To this end, the WUAs could be viewed as a vehicle for community building that spills over into other areas of lives of basin residents.

Concurrently, several factors - among those, geographic area, number of members, and historical context (Lalika et al. 2015) seem to present common challenges to both the functionality and sustainability of WUAs (Table 1). In terms of IWRM, WUAs may not equitably engage or represent all water users in a basin, especially smallholder farmers who dominate much of rural water use in Tanzania, given existing discrepancies in administrative capacity among stakeholders (van Koppen et al. 2016). Some studies suggest that the formal structure of WUA benefits those with experience navigating administrative processes and paperwork over those that are more accustomed to traditional resource management, like many rural residents (Sokile and van Koppen 2004, Komakech and van der Zaag 2011). Similarly, the formalized processes of WUAs may not always be aligned with the need for flexible decision making for smallholder farmers reliant upon irrigation water (Sokile et al. 2003, Sokile and van 
Koppen 2004, van Koppen et al. 2016). Several studies have examined ability and willingness of stakeholders to pay water fees and have found water fees difficult to enforce because of limited data on water resources; WUAs have not generally succeeded in bringing water abstractions in line with allocations (Maganga et al. 2004, Mehari et al. 2009). The WUAs struggle to obtain basic data on river flows, groundwater levels, or water quality. In terms of environmental sustainability, there is much room for WUAs to play an increased role in the determination and implementation of environmental flow recommendations, required for all major rivers under the NAWAPO (Anderson, personal observation). Many stakeholders - and often even WUA leadership — knowing that they get water from surface or groundwater sources, focus WUA efforts on water distribution and point of access. The fact that water sources need protection and that protection relies on local stakeholder involvement is sometimes overlooked.

Leadership and community participation in WUAs have also faced challenges. The WUAs require dynamic leaders able to enforce rules and refrain from favoritism, and adherence to established rules and guidelines. Sokile and van Koppen (2004) identified infrequent meetings and not following rules as pitfalls to WUAs in Tanzania. Many WUAs claim that they do not have enough funds for basic activities, nor vehicles or other means of transport to reach parts of the catchment for meetings or other activities. Some WUAs have brick and mortar offices, but a large number operate out of temporary or shared space. Office materials like computers and stationary, or Internet access, also are reportedly in limited supply. Different opinions exist on how to best respond to these operational and financial concerns. Some say that the Ministry of Water and Irrigation should have a line item in its budget for operational costs of WUAs, given that WUAs are part of the institutional framework for freshwater management. Others disagree and suggest that WUAs should raise money themselves, and the resultant funds would help to make them more sustainable and independent.

Limited capacity for management is reportedly another challenge to the functionality of WUAs. Although WUAs democratically form and appoint several committees (Table 2), many of those on the committees, or even sometimes the chairperson of the WUA, have little background or training in management. The WUAs are expected to report regularly to their respective BWB, but how to prepare these reports has been a challenge for many WUAs. The WUA leadership is tasked with navigating conflicts among stakeholders and ensuring compliance, but again often with little experience in these areas prior to the formation of the WUA. Finally, published studies from Tanzania have criticized WUAs for not sufficiently considering traditional or customary water management practices, or local conflict mediation processes (Sokile and van Koppen 2004, Komakech et al. 2011, Strauch and Almedom 2011).

\section{Case study: the Pangani Basin}

The Pangani Basin covers an area of $56,300 \mathrm{~km}^{2}$, nearly entirely within Tanzania, and hosts a human population of about 3.8 million people. The basin's landscape covers all or part of 18 districts within Tanzania and some of the major tourism areas near Arusha, Manyara, and Kilimanjaro. The Pangani Basin has been a pioneer and a test case for Tanzania's legal and institutional frameworks for IWRM, evidenced by numerous studies (see
Maganga et al. 2004, Komakech and van der Zaag 2011, Lalika et al. 2015, van Koppen et al. 2016). It was the first river basin in Tanzania to have a BWO/BWB and the first to undergo a complete environmental flow assessment; the formation of WUAs was initiated here earlier than in other basins. Since 2010, the Pangani BWB has facilitated establishment of at least 12 WUAs, prioritizing those areas with the most intense challenges. Many of those areas-especially those in the Kikuletwa-Ruvu catchment, served by the water towers of Mounts Meru and Kilimanjaro - are characterized by high social and economic diversity. International organizations - such as the International Union for the Conservation of Nature (IUCN) and the Deutsche Gesellschaft für Internationale Zusammenarbeit (GTZ) - have contributed both financial and technical support for implementing Tanzanian water legislation in the Pangani, including WUAs.

As related to IWRM, WUAs in the Pangani have created a network of nested institutions for WRM and formalized multistakeholder platforms. Specific areas where positive gains have been achieved include: water monitoring through traditional and smart-stick technology in pilot areas of the basin; increased capacity of water users to resolve conflicts; enhanced protection of riparian buffer areas through community-based initiatives; regular discussion among stakeholders about the changing river regime, equitable water allocation and water quality; and improved participation of women in water governance. These advancements have helped garner support for WRM in the Pangani, and for the WUAs in particular, as they have addressed several issues of concern across the basin (Kabogo, personal observations). But some authors have suggested that WUAs have missed an opportunity to strengthen existing or traditional water management arrangements at a local level rather than create new institutions, arguing that traditional systems allow for more equitable access to water (Maganga et al. 2004, Komakech and van der Zaag 2011). Sustainability of WUAs might benefit from greater flexibility to consider and adopt both customary and official legal channels in WRM.

Pangani WUAs also offer lessons on the importance of leadership, community participation, and finance in WUAs. One WUA in the Pangani reportedly collapsed due to failure of leaders to convene regular meetings, and others have suffered problems of favoritism, inefficiency in management, and lack of financial transparency (Lalika et al. 2015). Lack of awareness of the role of the WUAs and indifference of many stakeholders to comply with water-related policies are also challenges; the WUAs in general have not shown the capacity to turn this situation around. The WUAs in the Pangani also have the challenge of bringing together upstream and downstream water users for common agreement on water use, especially during dry periods. Diverse stakeholders-ranging from villages to major agricultural operations to urban water utilities to industry to protected areas' ecosystems - all depend on water in the Pangani. Forming coalitions and including participation of all of these stakeholders in WRM has proven to be an iterative, complex process. Increasing awareness and building capacity of WUA members - especially smallholder farmers-would help address several of these sustainability concerns for WUAs in the Pangani (Lalika et al. 2015). 


\section{Case study: the Wami/Ruvu Basin}

The Wami/Ruvu Basin covers an area of about $66,820 \mathrm{~km}^{2}$ just north of Dar es Salaam and drains to the Indian Ocean. The Wami/Ruvu Basin is an administrative designation created when the Wami/Ruvu Basin Water Board (WRBWB) was formed; the Wami and Ruvu are in fact two separate, but neighboring, hydrological systems. The Wami/Ruvu Basin's human population is estimated at 5.4 million (2002 population census), and rivers are important sources of water supply for meeting human needs. For example, much of the water for Dar es Salaam, Tanzania's largest city, is drawn from the lower Ruvu River, as is water supply for other large cities like Morogoro or Bagamoyo. To date, at least 16 WUAs have been registered in the Wami/Ruvu Basin, following official processes established by the Tanzanian government (Table 2). Many have received support from international collaboration projects. The earliest seven WUAs were formed in 2009 and focused on the Mkondoa and upper Wami sub-basins, and then three more WUAs were formed in 2010 in the Ngerengere subbasin. The remaining WUAs were formed between 2011-2013. The support for establishment of the WUAs came mainly from Water Sector Development Program funds, with the exception of three WUAs whose formation was financed by IUCN, and one funded through the USAID-Integrated Water, Sanitation, and Hygiene (iWASH) program. The USAID-iWASH program also supported a process to divide the Mkondoa WUA, originally formed in 2009, into three more manageable units. Nevertheless, compared with the Pangani and Rufiji Basins, there are very few published studies about WUAs and IWRM in the Wami/Ruvu in the primary literature.

Based on our observations, WUAs have contributed to IWRM in the Wami/Ruvu in four main ways. First, WUAs have helped with resolution of water-related conflicts, most commonly between upstream and downstream users, or between farmers and livestock keepers. The local presence of WUAs has been advantageous in conflict resolution, allowing for a better understanding of the history and the intricacies of conflicts than that typically possible for a basin-level institution. Second, WUAs have helped with building awareness in broad audiences of WRM and water-related legislation in Tanzania. The WUAs in the Wami/Ruvu are known to use brochures and posters, or even small plays where water-related scenarios are presented, to reach villagelevel audiences. The WUA members have also been involved in national events in support of the BWB and as representatives of the basin. Third, WUAs have been of assistance in collection of water-use fees. Fee collection presents a perennial challenge for the Wami/Ruvu BWB, largely because of limited access to water users in remote areas of the basin. The WUAs' local presence allows more direct contact with these water users, and as an incentive for assistance in collection of fees, the Wami/Ruvu BWB recently began allocating $20 \%$ of collected fees to support WUA activities. Fourth, WUAs in the Wami/Ruvu Basin have been involved in conservation measures designed to protect water sources for the basin. Examples include reforestation or tree planting projects in headwater and riparian areas, delineation of areas of protection around water sources, and development of community water resources monitoring programs.

The sustainability challenges faced by WUAs in the Wami/Ruvu are representative of those affecting WUAs throughout Tanzania. Of 16 WUAs in existence considered here, only one has an office of its own. The remaining WUAs rely on village government offices' space to perform their functions. Some WUAs have motorcycles and bicycles, but others lack transport and office supplies. Additionally, WUAs would benefit from more financial support, as most currently depend on a few water users that pay enrollment fees or those charged with fines. Inadequate public awareness of legal frameworks for water and conflicting roles and responsibilities for WRM further challenge the effectiveness of WUAs. Finally, there could be more follow-up and regular communication between the WUAs and the Wami/Ruvu BWB or the local government authorities. Capacities of executive members of most WUAs are relatively weak in terms of planning, coordination, and implementation of work plans and negotiation with different actors.

\section{Case study: the Lake Victoria (Mara) Basin}

For this case study, we focus on one of the major rivers in the Lake Victoria Basin: the Mara. The Mara River's basin, covering roughly $13,500 \mathrm{~km}^{2}$, is a transboundary system shared between Kenya $(65 \%)$ and Tanzania $(35 \%)$ and a subcatchment of the larger Lake Victoria Basin (LVB). It also drains the Serengeti National Park, offering one of the only perennial water sources and acting as a guidepost for the annual migration of thousands of wildebeests and other animals. The Lake Victoria BWB is the authority for WRM in the Mara Basin. International organizations have spearheaded numerous interventions in the Mara River Basin, Tanzania, to enable sustainable management of water resources, including support to WUAs.

To date, the LVBWB has managed to support the formation of at least six WUAs in the Mara: Upper Tigite, Lower Tigite, and North Mara WUAs in Tarime District; Tobora and Somoche River WUAs in Serengeti District; and South Mara Wetland WUA in Butiama District. Financial support for the formation of these WUAs came from Tanzania's Water Sector Development Programme (WSDP) and, in four cases, from the World Wide Fund for Nature (WWF). All six of these WUAs are now legal entities under the WRM Act of 2009, with defined corresponding areas of jurisdiction. The presence of the WUAs has measurably contributed to environmental management in the Mara Basin. For example, WUAs have organized education programs on environmental conservation and water pollution control for WUA members. Several WUAs have also engaged in tree planting campaigns in riparian areas, or mediated water resource-related conflicts among water users. Other WUAs have facilitated learning on income-generation activities, like cassava and banana farming, or sunflower production. All six WUAs in the Mara have constitutions, bank accounts, and clearly defined leadership, but only Somoche and Tobora River WUAs have temporary offices. As in the Wami/Ruvu, there are few or no published studies on WUA experiences in the Mara.

In terms of sustainability considerations, WUAs in the Mara offer several insights. Reports from the field to the Lake Victoria BWB document limited leadership capacity, lack of revenue, and absence of functional vehicles for transportation. Some WUAs have experienced confusion about their roles and authority, due to lack of awareness of relevant laws. There are also concerns about the cost of establishing new WUAs, and whether Tanzania should continue to depend on financial resources from international organizations for the WUA formation process as 
has happened in the Mara with the support from the WWF. The WUAs reportedly are technically unprepared to address some of the issues facing the catchments they manage. For instance, the Tobora WUA in the Serengeti District has struggled with halting or managing deforestation along water courses; much of this deforestation is associated with expansion of tobacco plantations or with cutting of trees for charcoal, as this region is considered to have among the highest quality wood for charcoal in the country. The Tigite WUAs, located in Tarime District and within a region of extensive gold mining, struggle to respond to problems of water pollution associated with mining activities. Both Tobora and Tigite WUAs would likely benefit from additional training specific to the situations in their catchments.

A lesson from the Mara has been that dynamic leadership can help weather some of the challenges characteristic to WUAs in the Mara Basin and throughout Tanzania, as also suggested from other literature (Brown 2011). The Tobora WUA, which manages the Tobora River subcatchment, a tributary of the Mara River, in 2015 was awarded best WUA in the Mara Basin - considering both Kenya and Tanzania - for its exemplary management and success in facilitating stakeholder participation. Discussions with people in the basin suggest that much of the Tobora WUA's success can be attributed to its chairperson, who has developed a reputation for being both fair and fearless (E. Anderson, unpublished data). Whereas other Mara WUAs struggle to enforce Tanzanian regulations as related to land use in riparian zones or permitted water extraction by the private sector, the Tobora WUA's chairperson has worked hard to enforce regulations and ensure fairness in decision making. The Tobora WUA has also created opportunities for income generation for the WUA through subprojects, most notably tree nurseries and beekeeping.

\section{CONCLUSIONS}

This paper has offered a summary of the recent progress in Tanzania as related to stakeholder participation and offered firsthand insights from two basins with little published information on WUAs (Mara, Wami/Ruvu). As late as 2003, some considered public participation in WRM in Tanzania to be quite low (Dungumaro and Madulu 2003). This paper documents advances and hindrances for WUAs since that time. Rather than viewed as one large step, we suggested the institutional changes brought by Tanzanian WUAs should be viewed as a sequential and incremental process (see Ostrom 1990).

Based on this review, we offer one final recommendation: create spaces for shared learning and collaboration among WUAs across Tanzania. In the existing literature and in our own experiences, many WUAs across Tanzania are reporting similar sustainability challenges (e.g., outlined in Table 1). The creation of a semiannual or annual meeting of WUA chairpersons across Tanzania, or other networking platforms, would help to facilitate shared learning and collaboration among WUAs. A regular forum would allow for exchange of experiences and could also provide opportunity for training for WUA leaders as related to sustainable management of water resources.

Responses to this article can be read online at: http://www.ecologyandsociety.org/issues/responses. php/9739

\section{Acknowledgments:}

This manuscript is the product of discussions between the authors during a socioenvironmental inventory of the Mara River Basin in March 2016 that involved in-person meetings with water users' associations in the basin. Support for this collaboration came from the Serengeti-Lake Victoria Sustainable Water Initiative, funded generously by The MacArthur Foundation. The authors thank colleagues at the Tanzanian Ministry of Water (G. Lugomela, H. Sadiki) and Florida International University (A. Lemos, J. Veilleux) for input to the thought process for this article and for these institutions' commitment to sustainable freshwater resources management in Tanzania. We also thank two anonymous reviewers for insightful and constructive comments that greatly improved this manuscript. Additional thanks go to the organizers of this special issue.

\section{LITERATURE CITED}

Becker, C. D., and E. Ostrom. 1995. Human ecology and resource sustainability: the importance of institutional diversity. Annual Review of Ecology and Systematics 26:113-133. http://dx.doi. org/10.1146/annurev.es.26.110195.000553

Brown, J. 2011. Assuming too much? Participatory water governance in South Africa. The Geographical Journal 177 (2):171-185. http://dx.doi.org/https://doi.org/10.1111/ j.1475-4959.2010.00378.x

Butler, C., and J. Adamowski. 2015. Empowering marginalized communities in water resources management: addressing inequitable practices in participatory model building. Journal of Environmental Management 153:153-162. http://dx.doi.org/10.1016/ j.jenvman.2015.02.010

Cleaver, F., and A. Toner. 2006. The evolution of community water governance in Uchira, Tanzania: the implications for equality of access, sustainability, and effectiveness. Natural Resources Forum 30:207-218. http://dx.doi.org/10.1111/ j.1477-8947.2006.00115.X

Cohen, J. M., and N. T. Uphoff. 1997. Rural development participation: concepts and measures for project design, implementation and evaluation. Rural Development Committee, Center for International Studies, Cornell University, Ithaca, New York, USA.

Dungumaro, E. W., and N. F. Madulu. 2003. Public participation in integrated water resources management: the case of Tanzania. Physics and Chemistry of the Earth 28:1009-1014. http://dx.doi. org/10.1016/j.pce.2003.08.042

Jacobs, K., L. Lebel, J. Buizer, L. Addams, P. Matson, E. McCullough, P. Garden, G. Saliba, and T. Finan. 2010. Linking knowledge with action in the pursuit of sustainable waterresources management. Proceedings of the National Academy of Sciences of the United States of America 113:17:4591-4596.

Komakech, H. C., and P. van der Zaag. 2011. Polycentrism and pitfalls: the formation of water users forums in the Kikuletwa catchment, Tanzania. Water International 38:231-249. http://dx. doi.org/10.1080/02508060.2013.791763

Komakech, H., B. van Koppen, H. Mahoo, and P. van der Zaag. 2011. Pangani River Basin over time and space: on the interface 
of local and basin level responses. Agricultural Water Management 98:1740-1751. http://dx.doi.org/10.1016/j.agwat.2010.06.011

Lalika, M. C. S., P. Meire, and Y. M. Ngaga. 2015. Exploring watershed conservation and water governance along Pangani River Basin, Tanzania. Land Use Policy 48:351-361. http://dx. doi.org/10.1016/j.landusepol.2015.06.010

Maganga, F. P. 2003. Incorporating customary laws in implementation of IWRM: some insights from Rufiji River Basin, Tanzania. Physics and Chemistry of the Earth 28:995-1000. http:// dx.doi.org/10.1016/j.pce.2003.08.011

Maganga, F. P., H. L. Kiwasila, I. H. Juma, and J. A. Butterworth. 2004. Implications of customary norms and laws for implementing IWRM: findings from Pangani and Rufiji Basins, Tanzania. Physics and Chemistry of the Earth 29:1335-1342. http://dx.doi.org/10.1016/j.pce.2004.09.008

Mehari, A., B. van Koppen, M. McCartney, and B. Lankford. 2009. Unchartered innovation? Local reforms of national formal water management in the Mkoji sub-catchment, Tanzania. Physics and Chemistry of the Earth 34:299-308. http://dx.doi. org/10.1016/j.pce.2008.07.009

Ostrom, E. 1990. Governing the commons. Cambridge University Press, Boston, Massachusetts, USA. http://dx.doi.org/https://doi. org/10.1017/CBO9780511807763

Sokile C. S., J. J. Kashaigili, and R. M. J. Kadigi. 2003. Towards an integrated water resource management in Tanzania: the role of appropriate institutional framework in Rufiji Basin. Physics and Chemistry of the Earth 28:1015-1023. http://dx.doi. org/10.1016/j.pce.2003.08.043

Sokile, C. S., and B. van Koppen. 2004. Local water rights and local water user entities: the unsung heroines of water resource management in Tanzania. Physics and Chemistry of the Earth 29:1349-1356. http://dx.doi.org/10.1016/j.pce.2004.09.010

Strauch, A. M., and A. M. Almendom. 2011. Traditional water resources management and water quality in rural Tanzania. Human Ecology 39:93-106. http://dx.doi.org/10.1007/s10745-011-9376-0

Subramanian, A., N. V. Jagannathan, and R. Meinzen-Dick. 1997. User organizations for sustainable water services. World Bank, Washington, D.C., USA. http://dx.doi.org/10.1596/0-8213-3855-2

United Republic of Tanzania (URT). 2002. The Water Policy. Government Printer, Dodoma, Tanzania.

United Republic of Tanzania (URT). 2009. The Water Resource Management Act. Government Printer, Dodoma, Tanzania.

van Koppen, B., A. K. P. R. Tarimo, A. van Eeden, E. Manzungu, and P. M. Sumuni. 2016. Winners and losers of IWRM in Tanzania. Water Alternatives 9(3):588-607.

Vollan, B., and E. Ostrom. 2010. Cooperation and the commons. Science 330:923-924. http://dx.doi.org/10.1126/science.1198349 